\title{
Understanding Indoor Play in Deaf Children: An Analysis of Play Behaviors
}

\author{
Millicent M. Musyoka \\ Lamar University, Beaumont, TX, USA \\ Email: mmusyoka@lamar.edu
}

Received 8 December 2014; revised 22 December 2014; accepted 8 January 2015

Copyright (C) 2015 by author and Scientific Research Publishing Inc.

This work is licensed under the Creative Commons Attribution International License (CC BY). http://creativecommons.org/licenses/by/4.0/

(c) (i) 0pen Access

\begin{abstract}
Play is an important element of cognitive, social and language development. Most preschool classrooms provide opportunity for indoor play and studies are needed to improve indoor play contexts for all children, including deaf children. The present study documented and described the play behaviors of Ann, a four-year-old native American Sign Language (ASL) deaf child in an ASL/ English bilingual classroom. Ann engaged in various play behaviors, in different play centers, and with different play partners. The sample consisted of 22 play episodes collected over a period of one year. A combination of social and cognitive play behavior categories based on Rubin's (2001) Play Observation Scale were used for documenting and the coding of the play behaviors observed. The results revealed that Ann was capable of engaging in developmentally appropriate play behaviors that were similar to those reported for hearing children her age. In addition, her play behaviors varied in relation to the play context and play partners. Teacher's decisions and control of play in the classroom appeared to have an impact on the play behaviors Ann demonstrated.
\end{abstract}

\section{Keywords}

Deaf Children, Play Behavior, Preschool Play, Indoor Play, ASL/English Bilinguals

\section{Introduction}

Children's play is an important aspect of a child's life that provides an opportunity to develop and test aspects of the cognitive and linguistic social worlds. Previous work shows that language, cognitive and social domains have a significant impact on children's play. These three domains include the same types of schemata and cognitive structures that represent objects (McCune-Nicolich, 1981; McCune-Nicolich, 1995; Piaget, 1962). Cognitive and social-cultural theorists explain the interplay of language, cognition, and social interactions in children's play (Piaget, 1962; Vygotsky, 1962) and according to Piaget, language and cognition are inseparable be- 
cause language and cognition involve mental organization; these schemata guides how children interact and represents the world around them. Consequently, play is an activity where young children include objects and people to construct an understanding of their surrounding world. While Piaget (1962) emphasized language and cognition, Vygotsky $(1967,1978)$ emphasized social interaction. He suggested that a child's cognitive and linguistic developments are a factor of society and culture. Hence, Vygotsky viewed play as a social interactive activity that involves others and requires language to facilitate the construction and sharing of knowledge used in the play.

Previous studies of hearing children show play behaviors consist of social behaviors (Parten, 1932), cognitive behaviors (Piaget, 1962; Smilansky, 1968), or a combined matrix of social-cognitive play behaviors (Rubin, 2001). Additionally, research suggests that play behavior is influenced by the play contexts and play materials (Henniger, 1985; Larson et al., 1990; McLoyd, 1983; Pellegrini \& Galda, 1982; Pellegrini et al., 1984; Shim et al., 2001) and play partners (Doyle et al., 1980; Matthews, 1978; Hadley \& Rice, 1991; Hartup, 1978; Howes, 1983; Howes et al., 1994; Rice, 1993).

Rubin's (2001) play observation scale included social play behavior categories (solitary, parallel, and cooperative play behaviors) and cognitive play behaviors categories (functional play, constructive play, pretend/dramatic play, and games with rules). As a combined matrix, the play behaviors were identified, as solitary functional, solitary constructive, parallel constructive, parallel dramatic, cooperative dramatic, cooperative constructive, and so forth. Based on the combined matrix, young four-year-old children were reported to demonstrate parallel constructive, cooperative-dramatic and cooperative-constructive (Smith 1978, Rubin et al., 1978). During parallel play, the child engaged in similar activities alongside peers. While in cooperative play, the child and peer played together. Respectively, with constructive play, the child engaged in creating objects or building. For dramatic play, the child engaged in social pretend play with other peers in which they planned and communicated their pretend play assigned roles, modified play script, or developed a play script.

In the area of deaf children's social-cognitive behaviors in play, there is a scarcity of research on the behaviors of deaf preschoolers between the ages of three and five years. Previous studies have shown that deaf children who have deaf mothers, who use ASL, exhibit play behaviors and interactions similar to those of their hearing peers with hearing mothers, because of the early access to visual communication and language (Spencer, 1996; Spencer \& Meadow-Orlans, 1996; Spencer \& Deyo, 1993; Spencer et al., 1991). The children in these studies were mostly infants and toddlers ages nine to thirty months. Importantly, studies conducted with deaf preschoolers have not focused on the use of ASL, a visual language accessible to deaf children, as a critical variable (Brackett \& Henniges, 1976; Darbyshire, 1977; Cornellius \& Hornett, 1980; Esposito \& Koorland, 1989; Gatty, 1990; Gregory \& Mogford, 1983; Higginbotham \& Baker, 1981; Krestchmer, 1972; Mann, 1984; Schirmer 1989). The findings in these studies were not entirely consistent and also demonstrated deaf children's play behaviors were inferior when compared to those of their hearing peers. Additionally, research suggests that play behavior is influenced by the play contexts and play materials, (Henniger, 1985; Larson, Greenfield \& Land, 1990; McLoyd, 1983; Pellegrini \& Galda 1982; Pellegrini, Galda \& Rubin, 1984; Shim, Herwig \& Shelley, 2001) and play partners (Doyle et al., 1980; Matthews, 1978; Hadley \& Rice, 1991; Hartup, 1978, 1983; Howes, 1983; Howes et al., 1994; Rice, 1993).

Many educators believe that play is integral in the early childhood teaching and learning process (Bennet et al., 1997; Ruff \& Lawson, 1990; Hanline et al., 2001; Saracho \& Spodek, 1995; Wood \& Atfield, 1996). Given the importance of play and the scarce research on deaf children' play in classrooms, the purpose of the this study was to learn more about deaf children's indoor play behaviors and to propose guidelines about the integration of play in classrooms with deaf children. Although it is a case study of one child, the in-depth description of the child's play behavior will add a new dimension to the knowledge of preschool deaf children's play behaviors. Specifically, the current research questions included; 1) What type of play behaviors does a native ASL Deaf child demonstrate in an ASL/English bilingual classroom? 2) To what extent do the play behaviors vary across different play settings in the classroom? 3) How do play partners influence the type of play behaviors? 4) How do teachers influence the play behaviors of deaf children in the classroom?

\section{Methodology}

\subsection{Signs of Literacy (SOL) Research Project}

The data source for this study was drawn from a larger set of data collected by the Signs of Literacy (SOL) re- 
search project. SOL data collection goal was to document and describe ASL-English biliteracy for deaf children from diverse cultural and linguistic backgrounds. The study site was an elementary school that serves deaf and hard of hearing children between birth through 15 years of age. The project data were collected over a three-year time span. The classroom videotape recording was done twice a month, from the beginning of the class day until lunchtime.

\subsection{Current Study}

The current study used one year of videotaped data collected in a preschool ASL/English bilingual classroom for four to five year-old deaf children. The study was part of a large project that investigated the play behaviors and language of native ASL deaf children play in an ASL/English bilingual classroom (Musyoka, 2013). Purposive sampling was used in selecting the classroom and participant who would be the focus of the current study. One of the six preschool classrooms, the "Older Playroom Classroom", where Ms. Karen and Ms. Jane were the teachers, was involved in the study. Ms. Karen and Ms. Jane are both native-ASL Deaf individuals. The teacher's assistant, Ms. Grace, is also Deaf and, while not native (born to Deaf parents), is a fluent user of ASL. The class had 12 children, out of which 8 had Deaf parents. The classroom was arranged for small- and large-group activities. Areas of the room were designated as play centers. In every session observed, the class was arranged with three play centers: three tables with chairs around them. During the year when the videotaped data were collected, the classroom had a total of ten play centers that were set up in varying configurations of three-at-a-time. These included Lego play, play dough, dramatic play, playing cards, rice play, farm animal play, mini block play, large block play, geo boards, and puzzle centers. While there was a variety of play material provided in all ten centers, the teachers decided the setting of each play center, which centers were available, and who joined which center.

The participant in this study was a four-year-old native ASL deaf child given the pseudonym of "Ann." Ann is a fourth generation deaf child with parents who are bilingual in ASL/English. Hence, she grew up always having full accessibility to language and deaf culture, which is something many deaf children do not have.

In observing, documenting and coding of the play behaviors that the child demonstrated in a period of one year, the Play Observation Scale (Rubin, 2001) was modified and used. The scale includes cognitive play categories (functional, constructive, exploration, dramatic and games-with-rules) nested within social play categories (solitary, parallel and group). This structure means there are 15 possible play behavior categories to be noted. A total of 22 play episodes observed during the one-year period were coded and analyzed. To code Ann's play behavior, each play episode was divided into segments defined as a 30-second observation unit, for a total of 625 segments. Ann's play behavior that occurred for the longest duration within a 30-second window was recorded. Alternatively, if more than one type of play behavior or equal play lengths were observed, the most mature of the social and cognitive behaviors was coded. During the coding process a peer de-briefer was involved. The Peer de-briefer is a native-ASL deaf person and one of the members of the SOL research team. The relationship between the researcher and the de-briefer was that of both the empathetic and critical other.

\subsection{Data Analysis}

Descriptive statistics including the use of frequencies and percentages were used to present quantitative descriptions of the data. This information was presented in the form of graphs or in tables showing the type of play behavior observed and how the play behavior varied across the play centers and play partners. The qualitative analysis included the main themes that emerged from data that described the nature of play behavior across various play centers and play partners. Also included was an observation report on how the teachers in the classroom influenced the nature of play behavior observed. Sample vignettes are provided to expound on the themes.

\section{Findings}

The analysis focused on the four main questions including: 1) What type of play behaviors does a native ASL deaf child demonstrate in an ASL/English bilingual classroom? 2) To what extent do the play behaviors vary across different play settings in the classroom? 3) How do play partners influence the type of play behaviors? 4) How do teachers influence the play behaviors of deaf children in the classroom?

Research question 1: what type of play behaviors does the deaf child demonstrate in an ASL/English bilingual classroom? 
The quantitative analyses demonstrated that Ann was capable of engaging in 13 different play behaviors in 22 play episodes. Most of her play behaviors were observed to occur infrequently: $0 \%-5 \%$ of the total playtime. Only three play behaviors-parallel constructive, cooperative constructive and cooperative dramatic-were observed more than $5 \%$ of the playtime. The frequency of the play behaviors is shown in Table 1 . The most frequent play behavior was parallel constructive play, which was observed 21.6\% (135 of the 625) of play times, whereas the least frequent was solitary dramatic play observed $0.5 \%$ ( 3 of the 625) of the playtime.

Research question 2: to what extent do the play behaviors vary across different play settings in the classroom?

In this study, play behaviors varied as a function of the play context, which included the play material and design of the play center. Ann demonstrated 13 types of play behaviors in the ten play centers. Figure 1 shows the distribution of the play behavior in the play centers.

Significant findings observed from the analysis of play behaviors in the play centers included the following.

Table 1. Frequencies of 30-second time segments of types of play behavior.

\begin{tabular}{ccc}
\hline Play behavior & Frequency & Percentage \\
\hline Solitary functional & 5 & $0.8 \%$ \\
Solitary constructive & 11 & $1.8 \%$ \\
Solitary dramatic & 3 & $0.5 \%$ \\
Parallel functional & 18 & $2.9 \%$ \\
Parallel constructive & 135 & $21.6 \%$ \\
Parallel dramatic & 31 & $5 \%$ \\
Parallel games with rules & 25 & $4 \%$ \\
Associative functional & 19 & $3 \%$ \\
Associative constructive & 35 & $5.6 \%$ \\
Cooperative functional & 5 & $0.8 \%$ \\
Cooperative constructive & 64 & $10.2 \%$ \\
Cooperative dramatic & 61 & $9.8 \%$ \\
Cooperative-games with rules & 26 & $4.2 \%$ \\
\hline
\end{tabular}

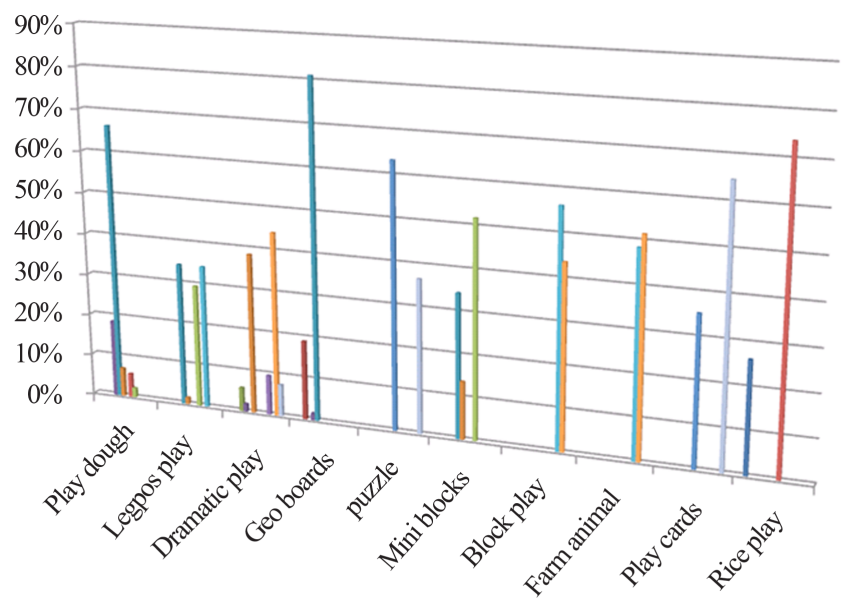

- Solitary functional

- Solirary constructive

- Solitary dramatic

- Parallel functional

- Parallel constructive

n- Parallel dramatic

- Parallel game with rules

n Associative functional

n Associative constructive

n Cooperative functional

n Cooperative constructive

m Cooperative dramatic

n Cooperative-games with rules 
1) Play behaviors varied across the play centers depending on the play material in each center. With materials such as large blocks and kitchen play toys (considered as social material), Ann demonstrated cooperative forms of play (cooperative dramatic and parallel constructive). On the other hand, with play dough and geo boards (considered as non-social play material), Ann's play behavior was more likely to be non-cooperative play (particularly, parallel constructive).

2) The design of the play centers tended to influence the type of play behavior observed. Some play centers were set as "on top-of-table play centers" in which she sat around the table with peers. While in "on-top-of-table play centers” (play dough, geo boards, Legos, and mini blocks) Ann was given her own individual share of the play material, and then played alongside the peer. The nature of play tended to involve constructive elements hence resulting in parallel constructive as the main play behavior.

3) Each play center had a dominant play behavior. For example, Ann spent most of her time (66.3\%) in the play dough center engaged in parallel constructive play, while, in the mini blocks center, most of her time (51.8\%) was engaged in the associative constructive type of play behavior. In the dramatic play center, she spent most of her time (44.2\%) engaged in cooperative dramatic play.

4) A wider variety of play behaviors was observed in certain play centers than others. Particularly striking, was the variety of play behaviors observed in the dramatic play center, the mini block play center, and the Lego play center. For instance in the dramatic play center alone she demonstrated, parallel functional, cooperative functional, parallel dramatic, solitary dramatic, cooperative dramatic and cooperative game with rules.

5) Some play behaviors were observed to occur in only one play center. For example solitary functional (rice play center), solitary constructive (geo boards play center), and solitary dramatic (dramatic play center) each occurred in only one play center.

Research question 3: how do play partners influence the type of play behaviors?

Ann's play behavior varied depending on who was in the play center with her. Ann demonstrated the ability to engage in cooperative play behavior (cooperative constructive, cooperative dramatic and cooperative game with rules) with three girls she considered as friends. Her friends are deaf from deaf families and had been in the preschool program for more than a year. With these friends, Ann was noted in several occasions initiating cooperative play. With other peers, whom she did not consider as a friend, the type of play behavior observed was primarily parallel (parallel constructive or parallel dramatic).

Research question 4: How do teachers influence the play behaviors of deaf children in the classroom?

Qualitative analysis showed the variation of play behaviors was a factor of the teacher's decisions. Ann was provided more opportunities to play in four of the ten centers including, play dough, geo boards, Legos, and mini blocks centers play centers compared to the other six centers. Parallel constructive play behavior was frequently demonstrated in these four assigned play centers. Occasionally, the teacher would set a kitchen center, a dress up center or large block building center. Cooperative play behavior (cooperative dramatic and cooperative constructive) occurred in dramatic and large block centers set up by the teacher. From time to time, Ann demonstrated a desire for more opportunities for cooperative play. Independently, she attempted to construct cooperative dramatic setting to role-play a teacher and s student with another peer. In other words, a number of the opportunities that Ann had to engage in parallel constructive play behavior were greater when compared to those of other play behaviors opportunities that could have occurred if the teachers had given her more similar opportunities in other centers such as dramatic, farm play and large block play centers.

Sampled vignettes of Ann's play behavior in selected play centers present a picture of Ann's three dominant play behaviors (parallel constructive, cooperative constructive and cooperative dramatic).

Vignette 1: parallel constructive play behavior at geo board center.

Ms. Jane leads Ann to geo board center. At the geo board center, there is a large table with chairs arranged around it. On the table is a pile of wooden geo boards, each with a pin array, beveled edges and a black acrylic surface to visually enhance geometric patterns. Accompanying the geo boards is a can with assorted colored rubber bands. Ann is alone at the center making shapes with the rubber bands on a wooden geo board. The play behavior observed was Solitary constructive. After a few minutes, Don and Ms. Jane joined Ann at the play center. Don sat opposite her. Don and Ann engaged in parallel play, constructing shapes on the geo board. The play behavior changes to Parallel Constructive. This type of play continued until Don left the play center. A few minutes later, Clara and Jean joined the play area. Just like Don, each picks a geo board and a can of rubber bands and plays alongside other peers.

Here, the teacher's decisions influenced the kinds of play that were found within the center. 


\section{Vignette 2: cooperative constructive in Lego play.}

Ann and two of her Friends, Carol and Jean, were in the Lego play center. Ann and Jean joined the Legos to make patterned columns while Carol was standing next to Ann watching the two play with the Legos. Carol points out Jean's Lego column to Ann.

Ann: You make one similar to Jean's. I will pick the Legos for you; then you join them.

(Ann picks the Legos for Carol, who joined them and made a similar patterned column as that of Jean. After a few minutes, Ann wanted to measure the column to make sure it is the same size as the one she had already made. Carol wanted to continue joining Lego and resists giving Ann the column).

Ann: I want to measure. You have joined enough; it is almost finished; leave it.

(Carol resisted, but let go of the Lego column).

Ann: Add these three more.

(She added the three Legos and Ann took the new Lego column and held them together with hers).

Carol: Are we friends?

(Carol stretched her hand to touch the finished Lego columns Ann was holding).

Ann: Nods.

What is clear is that the play center design, play materials and presence of her friends tend to influence the nature of play behavior.

Vignette 3: cooperative dramatic in role-play.

Ann asked Carol to role-play a teacher and student at the group morning meeting area, which had a writing board, as their pretend classroom. Because this area was not one of the play centers set by the teacher, Ann sought permission of the teacher before using the material.

Ann: Do you mind us playing with that?

Ms. Jane: It's fine. What do you want to do with the board?

Ann: I want to play with Carol and the board on how friends get mad.

Ms. Jane: Oh, it's fine if you want to use that. Ask Carol if she would like to play.

Ann: (Waved to Carol to get her attention) Do you want to play with this board? I will be a teacher and you a student. You will sit there facing me.

(Carol noded in agreement. She picked a chair and sat facing the teacher's board).

Ann: Where do I sit? (She moved to get her seat and placed it next to the board. After arranging the sitting positions for the students and teacher, the student began the role-play. Ann took the role of the teacher and Carol the student. After a while, the two-changed roles and Ann became the student and Carol the teacher).

Here Ann initiated cooperative play with one of her three friends.

\section{Discussions}

This study provided insights for understanding the nature of the play behaviors of one deaf child. The current study showed that Ann's play behaviors differed from those described in previous research with deaf children (Aymard, 1977; Brackett \& Henniges, 1976; Cornellius \& Hornett, 1980; Darbyshire, 1977; Esposito \& Koorland, 1989; Gatty, 1990; Gregory \& Mogford, 1983; Higginbotham \& Baker, 1981; Krestchmer, 1972; Mann, 1984; Schirmer, 1989). These earlier findings showed deaf children's play lacked social, language, and cognitive skills and categorized them as lacking in organization, as well as symbolic and dramatic play behaviors.

Examining Ann's play behavior (with and without friends) suggested that Ann's play demonstrated a developmental aspect because it showed overall higher frequencies of parallel constructive with cooperative-dramatic and cooperative-constructive emerging. Parallel constructive, cooperative-dramatic and cooperative-constructive characterize the play behavior that tends to occur among four-year-old children (Smith, 1978; Rubin et al., 1978). Further, parallel play behavior was found mostly when she was playing with her friends who were all girls. This finding is considered important because parallel constructive play behavior has been reported in previous studies as the dominant type of play behavior among girls (Rubin, Watson \& Jambor, 1978; Rubin et al., 1976).

Ann's play in this study was examined across ten play centers. The nature of play behavior appeared to differ across various play centers. The choice of toys and play material, as well as types of play spaces, varied across play center influenced Ann's play. For instance, in the large block play center, Ann demonstrated parallel constructive play; here both parallel constructive play and cooperative dramatic play were the main aspects of her 
play behavior. Alternatively, when she was in the play dough and geo board centers, her main play behaviors included solitary functional, solitary constructive and parallel constructive. These changing play behaviors seem to be consistent with the findings from other research which suggest that play centers influence children's play activities visible in their play behaviors (Pellegrini, 1986; Pellegrini \& Perlmutter, 1989). Hence, variations of play behaviors across play centers could be seen as signs of the impact of a play center on the Ann's play behavior and an important part of understanding the nature of play behavior.

The structure of the play center influenced the nature of play behaviors determined by the complexity, variety and amount to do in each play center (Kritchevsky \& Prescott, 1969). Complexity involved the possible opportunities for the child to manipulate and change the play centers to suit their play interests. Variety referred to the various types of play activities that a play center could provide. Amount to do referred to the number of choices that a particular play center provided for the child. In the current study, the teacher primarily used three tables to set up the play centers, which did not provide enough play space for the children to cooperatively play. Ann and her peers were observed to engage in more complex forms of play interaction when the play center was an open space such as a large block play center. For instance, parallel constructive play was observed mostly in geo boards play center because the set-up of the play dough center involved one round table around which all the children sat and played close to each other. In this center, the play space was limited to the table area and the seats provided. This set-up was similar to that observed in the play dough center, in which Ann demonstrated similar play behaviors as she did in play dough center.

This study showed that Ann's play behavior also varied depending on her play partner(s). In previous studies with hearing children, dramatic/pretend play occurred mostly among children who are familiar with each other (Doyle et al., 1980; Connolly et al., 1988). Ann was observed engaged in complex cooperative play with three peers categorized as friends, and who have all been together in the early childhood program over a longer period of time.

\section{Implications for Practice}

Most early childhood classroom have at least one play center, which means that the early childhood teacher recognizes the importance of play in early childhood education and makes serious attempts to integrate play into the curriculum. Some teachers who integrate play into their classroom learning and teaching have learned how to use play centers in ways that are the most beneficial for learning. Several themes emerged from the study that illustrate that the variability across play centers observed included play space, the structure of the play center, the material available in the play center, play partners and the teachers' role in setting and assigning children play centers. Armed with findings from the current study, on-going teacher, early childhood care givers and teacher preparation programs that focus on deaf children, can gain knowledge and skills on how to effectively design and use classroom play centers.

This study indicates that the classroom space needs to be adequate to allow children to engage in cooperative play behavior and also afford visually oriented deaf children a clear view of peers, teachers and others in the classroom. Decisions on the classroom space can affect the nature play behavior demonstrated and the expected learning outcome from the play (Morrow \& Rand, 1991). It is possible that well-intentioned teachers may experience ongoing frustration because they find themselves in a limited space to be able to offer opportunities for cooperative play behavior. For instance, in this classroom when the teacher set up to three table play centers, the space left at the corner of the classroom was limited, allowing few students to engage in cooperative play such as dressing up or dramatic kitchen play. Play centers, such as large block play, that required a large space of the classroom when presented became the whole class activity and the table play center were minimized. According to the National Clearinghouse for Educational Facility Planners International (2000) ECE classrooms should allot between 42 to 50 square feet per child to enable the child's need for movement, comfort, competence, and control (Olds, 2001).

Both pre-service and in-service training can support teachers in becoming aware of particular types of play center structures that are known to be conducive to early childhood development and emerging literacy. The structure of the play center appeared to influence the nature of Ann's play behaviors determined by the complexity, variety and amount to do in each play center (Kritchevsky \& Prescott, 1969). The structure of a play center determines the various types of play activities that can occur. "On-table-top" play centers, which include one round table around which all the children sit and play close to each other, there are limited opportunities for 
co-operative forms of play behaviors. For instance, parallel constructive play was observed mostly in the geo boards play center because of the set-up of the play center. In the case of the four-year-old deaf child in this study, organizing a classroom to include a Lego play center, large block play center, and a arm animal center would be considered developmentally appropriate. Hence the preschool teacher requires knowledge and skills to organize the classroom setting by paying attention to each child's needs, the structure of the play centers, play materials and play partners. Such knowledge empowers teachers to overcome the limitation of their individual classroom settings and embrace their important role in creating opportunities that will naturally promote variety of play behavior.

Besides the structure of the play center, teachers need knowledge and skills to stock the play centers with various play materials that will stimulate rich play behaviors. In addition, teachers need to be aware of the visual needs of the deaf child when interacting with the play materials. Play materials that require a deaf child to be visually engaged with the play material may impact their visual social engagement with others. For instance, when playing with the geo-board, Ann was observed to be physically (hands) and visually engaged with the rubber bands making it difficult for her to socialize and interact with others in cooperative play. Also, teachers need to equip the play setting with play material that can be used by more than one student, for more than one activity. For instance, in geo boards, Play dough, and puzzles play centers material presented had one apparent use and was designed for the use of only one student. In these centers Ann had to stay in one place (on a chair around the table) and used the play material alone to do one task, make shapes with the rubber bands (geo boards) or fitting in the puzzle pieces. In other centers, she demonstrated more flexibility and complexity in the use of the play material.

The preschool teacher needs to organize the classroom setting by paying attention to the play partners. The two most important characteristics identified in the current research that impact play behavior includes, familiarity to play partners and shared language ability. The teachers need to be able to assess their students' social and language skills and use these assessments when pairing student as play partners. Shared language is important for social interaction including play. Teachers need to be aware of their students' language ability and how they would impact the play behaviors in various setting. By attending to the child's social and language needs, the teacher can impact their play behaviors.

\section{Limitation and Directions for Future Research}

Although the findings are based on only one child, the in-depth analysis of the child is generally consistent with findings from other case studies that provide detailed information about a child's play behavior. This study focused on one girl who can be considered to be an archetypal deaf child, who had early access to language, and arrived in the preschool classroom having acquired language and ready for school. However this characteristic is not observed among most deaf preschoolers. This difference leads to various questions that need to be addressed when conducting research with young deaf children. These questions include; what if Ann's early language access was limited until upon arriving school, what would be the nature of her play behaviors? What if she had early language access but none of her deaf peers had similar early language benefit? What if Ann was a boy? What if the teacher's philosophy did not support play among deaf children? What if Ann was observed playing outside the classroom? These questions can be used to guide further research into the play behaviors of deaf preschool children in various preschool classrooms including those that offer and do not offer access to ASL language.

\section{References}

Aymard, L. L. (1977). Deaf and Hearing Children’s Play. Dissertation Abstracts International, 38, 1855B.

Bennet, N., Wood, L., \& Rogers, S. (1997). Teaching through Play: Teachers’ Thinking and Classroom Practice. Bristol, PA: Open University Press.

Brackett, D., \& Henniges, M. (1976). Communicative Interaction of Preschool Hearing Impaired Children in an Integrated Setting. The Volta Review, 78, 276-285.

Connolly, J.A., Doyle, A. \& Reznick, E. (1988). Social Pretend Play and Social Interaction in Preschoolers (Unpublished Masters Degree). Journal of Applied Psychology, 9, 301-313.

Darbyshire, J. (1977). Play Patterns in Young Children with Impaired Hearing. Volta Review, 79, 19-26.

Doyle, A., Connolly, J., \& Rivest, L. (1980). The Effect of Playmate Familiarity on the Social Interactions of Young Child- 
ren. Child Development, 51, 217-223. http://dx.doi.org/10.2307/1129609

Esposito, B. G., \& Koorland, M. A. (1989). Play Behavior of Hearing Impaired Children: Integrated and Segregated Settings. Journal of Exceptional Children, 55, 412-419.

Gatty, J. (1990). The Effects of Deafness on Play in Four-Year-Old Boys. Unpublished Dissertation, Amherst, MA: University of Massachusetts.

Gregory, S., \& Mogford, K. (1983). The Development of Symbolic Play in Young Deaf Children. In D. Rogers, \& J. A. Sloboda (Eds.), The Acquisition of Symbolic Skills (221-231). New York: Springer.

Hadley, A. P., \& Rice, L. M. (1991). Conversational Responsiveness of Speech- and Language-Impaired Preschoolers. Journal of Speech and Hearing Research, 34, 1308-1317. http://dx.doi.org/10.1044/jshr.3406.1308

Hanline, M. F., Milton, S., \& Phelps, P. (2001). Young Children’s Block Construction Activities: Findings from 3 Years of Observation. Journal of Early Intervention, 24, 224-237. http://dx.doi.org/10.1177/10538151010240030701

Hartup, W. W. (1978). Children and Their Friends. In H. McGurk (Ed.), Issues in Childhood Social Development (pp. 130-163). Cambridge: Cambridge University Press.

Hartup, W. W. (1983). Peer Relations. In E. M. Hetherington (Ed.), Handbook of Child Psychology: Volume 4. Socialization, Personality, and Social Development (pp. 103-196). New York: Wiley.

Henniger, M. L. (1985). Preschool Children’s Play Behaviors in an Indoor and Outdoor Environment. In J. L. Frost, \& S. Sunderlin (Eds.), When Children Play (pp. 145-149). Wheaton, MD: Association for Childhood Education International.

Higginbotham, D., \& Baker, B. (1981). Social Participation and Cognitive Play Differences in Hearing Impaired and Normally Hearing Preschoolers. The Volta Review, 83, 135-149.

Howes, C. (1983). Patterns of Friendship. Child Development, 54, 1041-1053. http://dx.doi.org/10.2307/1129908

Howes, C., Droege, K., \& Matheson, C. C. (1994). Play and Communication Processes within Long- and Short-Term Friendship Dyads. Journal of Social and Personal Relationships, 11, 401-410. http://dx.doi.org/10.1177/0265407594113006

Krestchmer, R. (1972). A Study to Assess the Play Activities and Gesture Output of Hearing Handicapped Preschool Children. Project No.45-2109, Cincinnati Speech and Hearing Center: US Department of Health, Education, and Welfare, Office of Education, Bureau of the Handicapped.

Kritchevsky, S., \& Prescott, E. (1969). Planning Environments for Young Children: Physical Space. Washington DC: NAEYC.

Larson, C. S., Greenfield, P. M., \& Land, D. (1990). Physical Environments and Child Behavior in Vienna Kindergartens. Children's Environments Quarterly, 7, 37-43.

Mann, L. F. (1984). Play Behaviors of Deaf and Hearing Children. In D. S. Martin (Ed.), International Symposium on Cognition, Education, and Deafness (pp. 27-32). Washington DC: Gallaudet University Press.

Matthews, W. S. (1978). Sex and Familiarity Effects upon the Proportion of Time Young Children Spend Playing in Spontaneous Fantasy Play. The Journal of Genetic Psychology, 133, 9-12. http://dx.doi.org/10.1080/00221325.1978.10533352

McCune-Nicolich, L. (1981). Toward Symbolic Functioning: Structure of Early Pretend Games and Potential Parallels with Language. Child Development, 52, 785-797. http://dx.doi.org/10.1111/j.1467-8624.1981.tb03115.x

McCune-Nicolich, L. (1995). A Normative Study of Representational Play at the Transition to Language. Developmental Psychology, 31, 198-120. http://dx.doi.org/10.1037/0012-1649.31.2.198

McLoyd, V. C. (1983). The Effects of the Structure of Play Objects on the Pretend Play of Low-Income Preschool Children. Child Development, 54, 626-635. http://dx.doi.org/10.2307/1130049

Morrow, L., \& Rand, M. (1991). Promoting Literacy during Play by Designing Early Childhood Classroom Environments. The Reading Teacher, 44, 396-403.

Musyoka, M. M. (2013). A Case Study of Native-ASL Deaf Child's Play in an ASL/English Bilingual Preschool Classroom: Play Behaviors, Interactions, and Language Use. ProQuest Dissertations and Theses, Order No. 3575136, Washington DC: Gallaudet University. http://search.proquest.com/docview/1459363731?accountid=7043

Olds, A. R. (2001). Child Care Design Guide. New York: McGraw Hill Book Company.

Parten, M. (1932). Social Participation among Preschool Children. Journal of Abnormal Psychology, 27, 309-314.

Pellegrini, A. D. (1986). Communicating in and about Play: The Effect of Play Centers on Preschoolers’ Explicit Language. In G. Fein, \& M. Rivkin (Eds.), The Young Child at Play: Reviews of Research (pp. 79-91). Washington DC: National Association for the Education of Young Children.

Pellegrini, A., \& Galda, L. (1982). The Effects of Thematic-Fantasy Play Training on the Development of Children's Story Comprehension. American Educational Research Journal, 19, 443-452. http://dx.doi.org/10.3102/00028312019003443

Pellegrini, A., Galda, L., \& Rubin, D. (1984). Context in Text: The Development of Oral and Written Language in Two Ge- 
nres. Child Development, 55, 1549-1555. http://dx.doi.org/10.2307/1130025

Pellegrini, A. D., \& Perlmutter, C. J. (1989). Classroom Contextual Effects on Children's Play. Developmental Psychology, 25, 289-296. http://dx.doi.org/10.1037/0012-1649.25.2.289

Piaget, J. (1962). Play, Dreams and Imitation in Childhood. New York: Norton.

Rubin, K. H. (2001). Play Observation Scale (POS). University of Maryland Center for Children, Relationships and Culture. http://www.rubin-lab.umd.edu/Coding\%20Schemes/POS\%20Coding\%20Scheme\%202001.pdf

Rubin, K. H., Maioni, T., \& Hornung, M. (1976). Free Play Behaviors in Middle- and Lower Class Preschoolers: Parten and Piaget Revisited. Child Development, 47, 414-419. http://dx.doi.org/10.2307/1128796

Rubin, K. H., Watson, K. S., \& Jambor, T. W. (1978). Free-Play Behavior in Preschool and Kindergarten Children. Child Development, 48, 534-536. http://dx.doi.org/10.2307/1128725

Ruff, H. A., \& Lawson, K. R. (1990). Development of Sustained, Focused Attention in Young Children during Free Play. Developmental Psychology, 26, 85-93. http://dx.doi.org/10.1037/0012-1649.26.1.85

Saracho, O. N., \& Spodek, B. (1995). Children’s Play and Early Childhood Education: Insights from History and Theory. Journal of Education, 177, 129-148.

Schirmer, B. (1989). Relationship between Imaginative Play and Language Development in Hearing-Impaired Children. American Annals of the Deaf, 134, 219-222. http://dx.doi.org/10.1353/aad.2012.0609

Shim, S., Herwig, J. E., \& Shelley, M. (2001). Preschoolers’ Play Behaviors with Peers in Classroom and Playground Settings (Statistical Data Included). Journal of Research in Childhood Education, 15, 149-154. http://dx.doi.org/10.1080/02568540109594956

Smilansky, S. (1968). The Effects of Socio-Dramatic Play on Disadvantaged Preschool Children. New York: Wiley.

Smith, P. K. (1978). A Longitudinal Study of Social Participation in Preschool Children: Solitary and Parallel Play Reexamined. Developmental Psychology, 14, 517-523. http://dx.doi.org/10.1037/0012-1649.14.5.517

Spencer, P. E. (1996). The Association between Language and Symbolic Play at Two Years: Evidence from Deaf Toddlers Child Development, 67, 867-881. http://dx.doi.org/10.2307/1131866

Spencer, P. E., Deyo, D., \& Grindstaff, N. (1991). Symbolic Play Behavior of Deaf and of Hearing Toddlers. In D. F. Moores, \& K. P. Meadow-Orleans (Eds.), Educational and Developmental Aspects of Deafness (pp. 390-406). Washington DC: Gallaudet University Press.

Spencer, P., \& Deyo, D. (1993). Cognitive and Social Aspects of Deaf Children’s Play. In M. Marschark, \& M. Clark (Eds.), Psychological Perspectives on Deafness (pp. 65-91). Hillsdale, NJ: Eribaum.

Spencer, P., \& Meadow-Orlans, K. (1996). Play, Language, and Maternal Responsiveness: A Longitudinal Study of Deaf and Hearing Infants. Child Development, 67, 3176-3191. http://dx.doi.org/10.2307/1131773

Vygotsky, L. S. (1967). Play and Its Role in the Mental Development of the Child. Soviet Psychology, 5, 6-18.

Vygotsky, L. S. (1978). Mind in Society: The Development of Higher Psychological Processes. Cambridge, MA: Harvard University Press.

Wood, E. A., \& Atfield, J. (1996). Play, Learning and the Early Childhood Curriculum. London: Paul Chapman. 
Scientific Research Publishing (SCIRP) is one of the largest Open Access journal publishers. It is currently publishing more than 200 open access, online, peer-reviewed journals covering a wide range of academic disciplines. SCIRP serves the worldwide academic communities and contributes to the progress and application of science with its publication.

Other selected journals from SCIRP are listed as below. Submit your manuscript to us via either submit@scirp.org or Online Submission Portal.
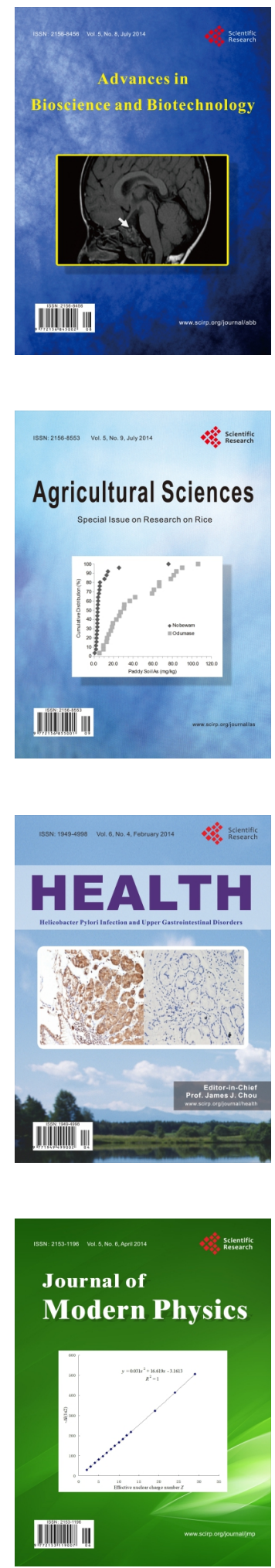
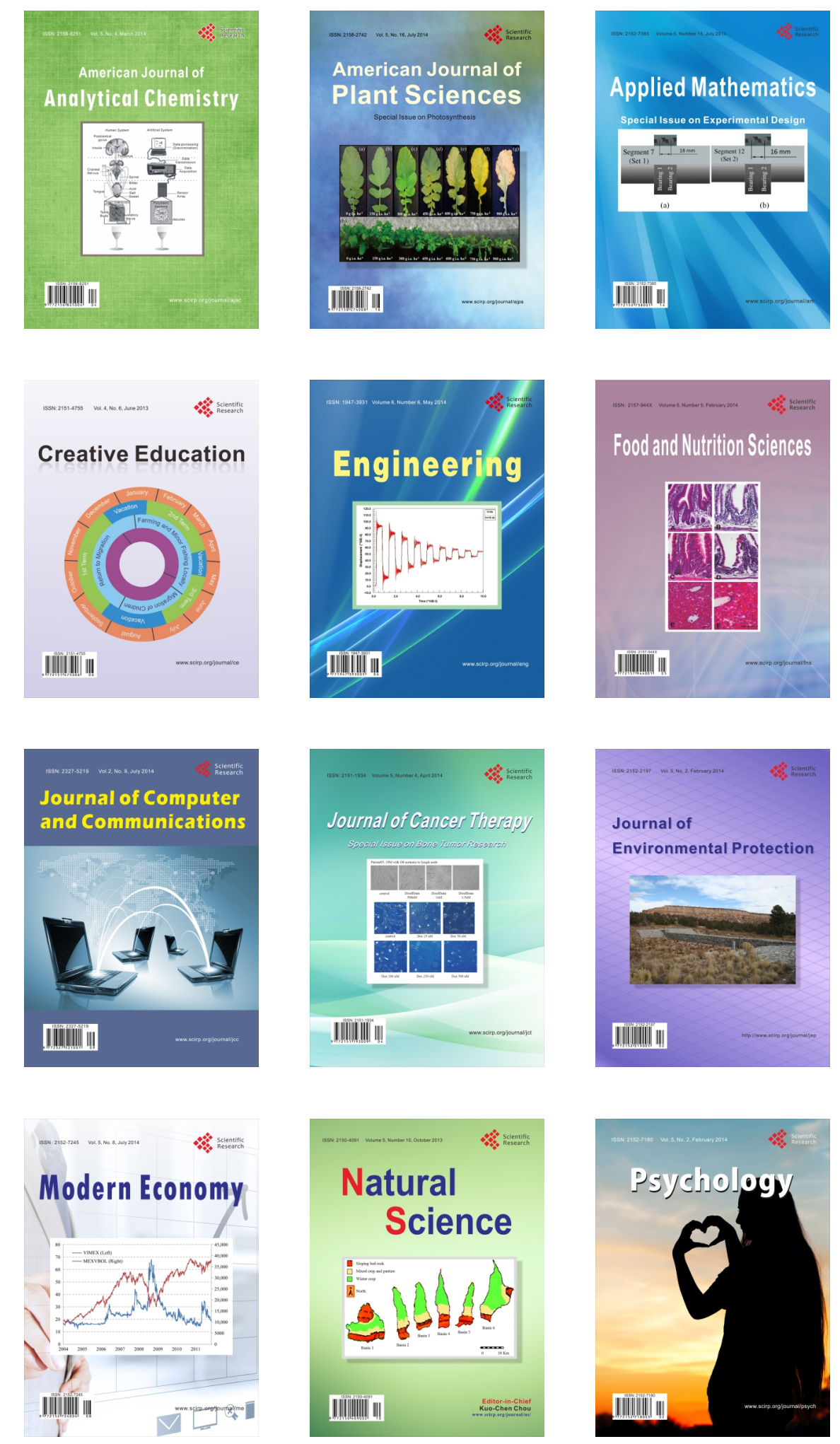